\title{
PREMATURE AGING AND STRUCTURAL ORGANIZATION OF THE MESENTERIC LYMPH NODE
}

\section{Olga Gorchakova ${ }^{1}$ (D), Natalya Kolosova ${ }^{2}$ (1) Vladimir Gorchakov $v^{1,3 凶} \otimes$ (i), Elena Starkova ${ }^{1,3}$ (1) Georgy Demchenko 4}

\section{${ }^{1}$ Research Institute of a clinical and experimental Lymphology - branch of Institute of Cytology and Genetics of the Siberian Branch of the Russian Academy of Science, Novosibirsk, Russia \\ ${ }^{2}$ Institute of Cytology and Genetics of the Siberian Branch of the Russian Academy of Science, Novosibirsk, Russia \\ ${ }^{3}$ Novosibirsk State University, Novosibirsk, Russia \\ ${ }^{4}$ Institute of Physiology of Human and Animals of Committee of Science of the Ministry of Education and Science of the Republic of Kazakhstan, Almaty, Kazakhstan}

\section{vgorchak@yandex.ru}

\begin{abstract}
The aim of the study was to estimate the structural organization of a mesenteric lymph node in comparative analysis at young rats of OXYS and Wistar. We used a morphological method of a research. The ageinduced changes of lymphoid tissue are various at Wistar and OXYS rats. The structural answer of a lymph node is optimum to three-months age of rats of Wistar. At the same time, we noted reduction of structures of cortical substance, especially lymphoid follicles and a paracortex, against the background of increase of medullary substance at OXYS rats. Observed changes of structure of lymph nodes are a morphological equivalent of premature aging and confirms early decrease of drainage and immune functions at OXYS rats.
\end{abstract}

KEYW ORDS — lymph node, premature aging, OXYS rats.

\section{INTRODUCTION}

The problem of aging has great interest from many experts of science and medicine. Until now there is no aging explanation, as well as is absent the universal theory of aging. The existing theories of lymphoid [1] and humoral [2] ageings need representation of morphological equivalents from lymphoid tissue including lymph nodes $[3,4,5]$. Age disturbances of structure and functions of peripheral lymphoid bodies lead to disturbance of an endoecological homeostasis against the background of decrease of a lymph flow and development of immune insufficiency [6].

The immune deficit is considered as aging manifestation. It was logical to assume that the premature (accelerated) aging at OXYS rats can be connected with morphology of regional lymph nodes. There is an urgent need of a morph of functional assessment of lymph nodes. Lymph nodes are an integral part of the general protective system of an organism in the lymphatic region $[5,6,7]$. Reactive changes of a design of lymph nodes not always find the explanation, especially, in presenilation.

The aim of the study is simultaneous assessment of the structural organization of a mesenteric lymph node of young rats of OXYS and Wistar.

\section{MATERIALS AND METHODS}

Rats of the Wistar and OXYS lines are received from Center of collective use "Gene pools of laboratory animals" of Institute of cytology and genetics of the SB RAS. N.G. Kolosova is a holder of the license for OXYS rats. These rats have genetically caused defect of metabolism with great content of oxygen radicals (oxidative stress), it is considered as an accelerated aging syndrome [8]. OXYS rats differ in low lifetime, early involute and pathological changes of internals, frequent developing of tumors in comparison with Wistar rats $[8,9,10]$.

The experiment was executed on young white rats of three-months age with a morphological research of mesenteric lymph nodes of caudal group. Lymph nodes fixed in $10 \%$ neutral formalin. After fixing we adhered to the classical scheme of washing, dehydration, imbibition with a xylol, paraffin and preparation histologic sections on the microtome. Histologic sections of lymph nodes painted hematoxylin and eosine, azure-II-eosine, trichromatic paint on Masson.

The morphometric analysis of structures of a lymph node was carried out by means of a morphometric grid and the Image-Pro Plus 4.1 program. Statistical data processing was performed with licensed statistical software package StatPlus Pro 2009, AnalystSoft Inc. Data were expressed as average arithmetic with definition of a standard (mean square) error. Belonging to normal distribution was defined when calculating criterion of Kolmogorov-Smirnov and the accompanying indicators. A P-value $<0.05$ was considered statistically significant.

\section{RESULTS}

The morphological analysis of results revealed certain differences of the structural organization of 
peripheral lymphoid organs of Wistar and OXYS rats in an experiment (Table 1, Fig. 1). Lymphoid tissue of rats of Wistar reaches optimum development to threemonths age [6]. Degree of a maturity of a parenchyma of lymph nodes is connected with their topographical localization and belonging to the lymphatic region $[5,7]$. Lymph nodes of young animals of Wistar have an intermediate morphotype when cortical and medullary substances are developed equally, proceeding from the value of cortical and medullary index $(1.33 \pm 0.14)$. It reflects rather high immune and drainage potential of lymph nodes in the "hepatoenteric" region (Table 1 ).

Table 1. Morphometric parameters of mesenteric lymph node structure of young Wistar and OXYS rats (three-months age), \%

\begin{tabular}{l|l|l}
\hline $\begin{array}{l}\text { Structures and indices } \\
\text { of the mesenteric lymph node }\end{array}$ & WISTAR & OXYS \\
\hline Capsule & $5.47 \pm 0.57$ & $5.54 \pm 0.62$ \\
\hline Subcapsular lymphatic sinus & $3.50 \pm 0.30$ & $2.65 \pm 0.26$ \\
\hline Cortical plateau & $7.63 \pm 0.45$ & $4.34 \pm 0.36^{*}$ \\
\hline $\begin{array}{l}\text { Lymphoid follicles } \\
\text { without germinative center }\end{array}$ & $3.30 \pm 0.26$ & $2.44 \pm 0.15$ \\
\hline $\begin{array}{l}\text { Lymphoid follicles } \\
\text { with germinative center }\end{array}$ & $5.06 \pm 0.25$ & $1.52 \pm 0.08^{*}$ \\
\hline Paracortex & $16.14 \pm 1.26$ & $5.66 \pm 0.31^{*}$ \\
\hline Medullary cords & $10.74 \pm 0.96$ & $15.75 \pm 0.93^{*}$ \\
\hline Medullary lymphatic sinus & $7.00 \pm 0.48$ & $4.69 \pm 0.65$ \\
\hline Total cross-sectional area & $58.83 \pm 2.55$ & $42.59 \pm 1.34^{*}$ \\
\hline
\end{tabular}

Note: ${ }^{*} P<0,05$ - statistical significance level between Wistar and OXYS rats.

We saw other morphological picture in mesenteric lymph nodes at young rats of OXYS in three-month age. First of all, the total area of cross-section of a mesenteric lymph node decreased in 1.4 times. It leads to change of the size of the majority of structural and functional zones of a lymph node in comparison with Wistar rats (table 1, fig. 1). So, the cortical plateau (in 1.7 times), lymphoid follicles with the germinative center (in 3.3 times), a paracortex (in 2.9 times) are reduced. Reduction of the area of cortical substance structures happens at increase of medullary substance in a mesenteric lymph node of rats of OXYS. The character dynamic change of structure is indicated also by the size of a cortical and medullary ratio, reaching $0.81 \pm 0.05$ (Table 1 ). Noted changes of structure of a lymph node demonstrate decrease of drainage and immune function at rats of OXYS in three monthly age.

\section{DISCUSSION}

The intestinal lymphatic region is a part of the general protective system of an organism and includes a tissue microregion with lymphoid follicles, vessels and lymph nodes [5]. It is in close contact with external environment that causes intake of antigenic material from an intestines gleam, and lymphoid tissue serves as a barrier on the way of this stream of antigens. Localization of a lymph node defines forming of morphological variant of structure according to the principle of a regional determinant $[6,7]$.

The age-induced changes of lymphoid tissue were various at rats of the Wistar and OXYS. Structural and functional zones of a lymph node reach the greatest development in rats of Wistar. The genetic defect at rats of OXYS led to lag of development of lymph nodes that is characterized by reduction of cortical substance structures against the background of increase in medullary substance. Barrier function of lymph nodes suffers. It is known that early involution of a thymus gland with decrease of the activity of the T-cellular link of the immune system is observed at OXYS rats [10,11]. A morphological equivalent is reduction of paracortical area in a lymph node.

At the same time also the area of lymphoid follicles with the germinative center decreases. Lymphoid follicles together with paracortical area participate in forming of the immune response. Regional lymph nodes actively react to any changes of drained areas, but the created structure of lymph nodes of OXYS rats does not provide adequate drainage and immune functions in the lymphatic region. Observed manifestations of the accelerated aging of peripheral lymphoid organs supplement the lymphoid and humoral theory of aging $[1,2]$.

\section{CONCLUSION}

Results of researches allow to draw a conclusion that the structural disorganization of peripheral lymphoid tissue developing at OXYS rats occurs earlier and characterizes premature aging and possible risk of developing of pathology. It is expressed in minimization of cortical substance structures and increase of medullary substance of lymph nodes. These changes are caused with features of the intestinal lymphatic region. The found morphology of lymph nodes allow to consider OXYS rats as universal model of immune insufficiency. It needs to be considered at a research of pathogenesis and creation of correction methods at premature aging.

\section{REFERENCES}

1. Dontsov V.I., KRUtKo V.N. Aging: system approach // Collection of articles. Reports of MOIP. 
Fig. 1. The share of structures from the area of mesenteric lymph node taken as $100 \%$ in Wistar and OXYS rats. C - capsule, $\mathrm{C} p$ - cortical plateau, Lf-lymphoid follicles, $P$ - paracortex, $M c$ - medullary cords, Ls - lymphatic sinus
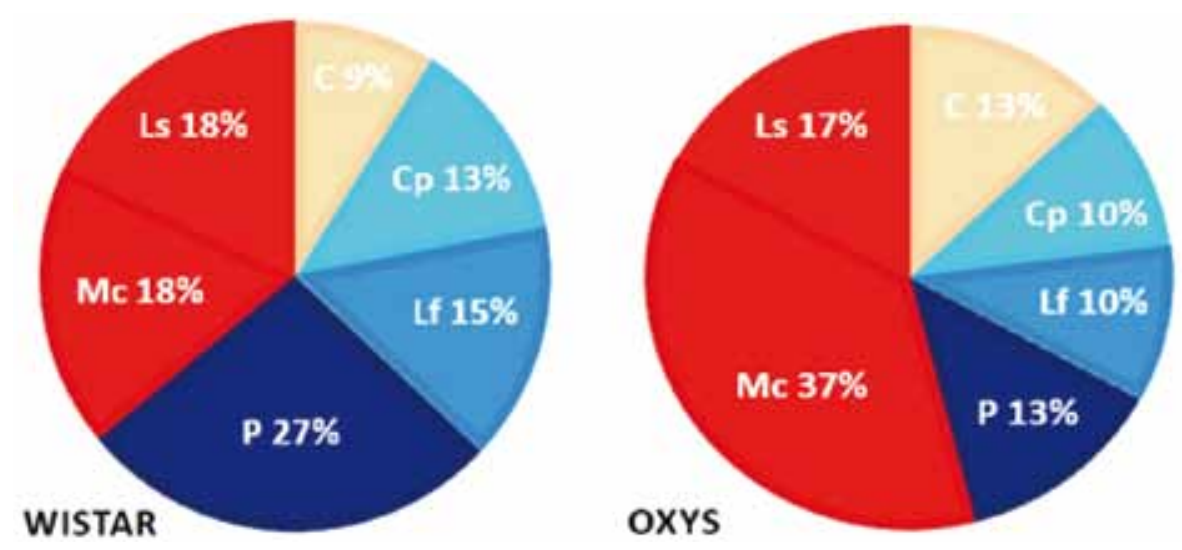

Gerontology section. - M.: Tsifrovichek, 2015. - Vol. 59. - P.22-37. [In Rus.]

2. Toporova S.G. Features of a system of pericellular humoral transport when aging: overview of literature // Almanac "Gerontology and Geriatric". - M, 2003. - Issue 2. - P.90-94. [In Rus.]

3. Passos J., Zglinicki T., Kirkwood T.B. Mitochondria and ageing: winning and losing in the numbers game // Bioassays. - 2007. - Sep. - V. 29 (9). - P. 908-917.

4. Chernilevsky V.E., Kudashov A.A. The main methodical mistakes, myths and stamps in the general analysis of a problem of aging // the Collection of articles. Reports of MOIP. Gerontology section. - M.: Tsifrovichek, 2015. - Vol. 59. - P. 3-11. [In Rus.]

5. Borodin Yu.I., Gorchakova O.V., Gorchakov V.N. Peripheral lymphoid structures: formation and function / / Morphology. - 2016. - Vol. 150. Issue 4. P. 90-96. [In Rus.]

6. GORCHAKOVA O.V., GORCHAKOV V.N. Increase in drainage and immune functions of a lymph node as a factor of endoecological wellbeing at advanced and senile age // ADVANCES IN GERONTOLOGY. 2015. - Vol. 28. - No. 3. - P. 521-526.

7. Borodin Ju.I., Gorchakova O.V., SuhOVERShiN A.V., Gorchakov V.N., Fartukov A.V., KolMOgOROV Ju.P., DemChenko G.A. The concept of lymphatic region in preventive lymphology. LAP LAMBERT Academic Publishing. 2018. - 74 p.

8. Kolosova N.G., Aydagulova S.V., NepomnjasHCHIH G.I. Dynamics of structural and functional changes of mitochondrions of hepatocytes of prematurely aging rats of the OXYS line // Bulletin exper. biol. - 2001. - Vol. 132. - No. 8. - P. 235-240. [In Rus.]

9. Kolosova N.G., Stefanova N.A., Korbolina E.E., Fursova A.ZH. AND KozheVnikova O.S. Senescence-Accelerated OXYS Rats: A Genetic Model of Premature Aging and Age-Related Diseases // ADVANCES IN GERONTOLOGY. - 2014. Vol. 27. - No. 2. - P. 336-340.
10. Obukhova L.A., Skulachev V.P., Kolosova N.G. Mitochondria-targeted antioxidant SkQ1 inhibits age-dependent involution of the thymus in normal and senescence-prone rats // AGING. - 2009. - V. 1(4). - P.389-401.

11. Markova E.V., Obukhova L.A., Kolosova N.G. Indicators of activity of a cellular link of the immune response of rats of the Wistar and OXYS lines and feature of their behavior in the test of "open field" / / Bulletin exper. biol. - 2003. - Vol. 136. - No. 10. P.427-429. [In Rus.] 